\title{
Nodular Splenic Sarcoidosis: A Rare Case Report
}

\author{
Nodüler Splenik Sarkoidoz: Nadir Bir Olgu
}

Mustafa Çalık', Mihrican Yesildag², Saniye Göknil Çalık³ ${ }^{3}$ Tahir Taha Bekci², Hıdır Esme

\begin{abstract}
Sarcoidosis is an idiopathic, multi-systemic, granulomatous disease. It most commonly involves the lungs. Herein, we present a rare and usually asymptomatic case with splenic sarcoidosis without liver involvement. A 31 -year-old male patient was admitted to our clinic with cough, sputum, and shortness of breath. He reported no common systemic complaints of sarcoidosis. Thoracic and abdominal computed tomography showed multiple hypodense mediastinal lymph nodes with splenic involvement. No other intra-abdominal pathology or peripheral lymphadenopathy was detected. Mediastinoscopy was performed. Diagnosis was made histopathologically. Following the treatment, his complaints regressed. Nodular splenic involvements are uncommon. Although there have been reported thirty-nine cases of sarcoidosis with multiple nodular hepatic and splenic lesions, only three isolated splenic cases have been reported in the literature to date. Despite its rarity, extra-pulmonary sarcoidosis may cause significant morbidity and mortality. Therefore, we discuss this case to draw attention to splenic sarcoidosis without liver involvement and its manifestations, diagnosis, and clinical course.
\end{abstract}

Key words: Sarcoidosis, splen, intra-abdominal, splenic involvement, nodular.

\section{Özet}

Sarkoidoz idiyopatik multisistemik granülomatöz bir hastalıktır. En sık akciğerleri tutar. Biz nadir ve genellikle asemptomatik karaciğer tutulumu olmayan nodüler splenik sarkoidozlu bir olguyu sunduk. Otuz bir yaşındaki erkek hasta; öksürük, balgam ve nefes darlığı şikâyetleriyle kliniğimize başvurdu. Sarkoidozun yaygın sistemik bulgularından hiçbirine rastlanılmadı. Toraks ve batın BT incelenmesinde çok sayıda hipodens mediastinal lenf nodları ve dalak tutulumu vardı. Başka intra-abdominal patoloji veya periferik lenfadenopati saptanmadı. Mediastinoskopi yapıldı. Tanısı histopatolojik olarak doğrulandı. Tıbbi tedaviden sonra şikâyetleri azaldı. Nodüler splenik tutulumu nadirdir. Sarkoidozun; multiple karaciğer ve splenik tutulumu olan otuz dokuz olgu rapor edilmesine rağmen, sadece üç izole nodüler splenik tutulum literatürde bildirilmiştir. Nadirliği nedeniyle ekstrapulmoner sarkoidoz önemli morbidite ve mortaliteye neden olabilir. Bu nedenle, karaciğer tutulumu olmayan nodüler splenik sarkoidozun, belirtileri, tanısı ve klinik seyrine dikkat çekmek amacıyla bu olguyu sunduk.

Anahtar Sözcükler: Sarkoidoz, dalak, intra-abdominal, dalak tutulumu, nodüler. $\begin{array}{ll}\text { 'Department of Thoracic Surgery, Health Sciences University, Kon- } & \text { 'Sağlık Bilimleri Üniversitesi Konya Eğitim ve Araştırma Hasta- } \\ \text { ya Training and Research Hospital, Konya, Turkey } & \text { nesi, Göğüs Cerrahisi Kliniği, Konya } \\ { }^{2} \text { Department of Pulmonary Medicine, Health Sciences University, } & { }^{2} \text { Sağlık Bilimleri Üniversitesi Konya Eğitim ve Araştırma Hasta- } \\ \text { Konya Training and Research Hospital, Konya, Turkey } & \text { nesi, Göğüs Hastalıkları Kliniği, Konya } \\ { }^{3} \text { KTO Karatay University Vocational School of Health Services, } & { }^{3} \text { KTO Karatay Üniversitesi Sağlık Hizmetleri Meslek Yükseko- } \\ \text { Konya, Turkey } & \text { kulu, Konya }\end{array}$

Submitted (Başvuru tarihi): 23.12.2015 Accepted (Kabul tarihi): 09.05.2017

Correspondence (iletişim): Mustafa Çalık, Department of Thoracic Surgery, Health Sciences University, Konya Training and Research Hospital, Konya, Turkey

e-mail: drmcalik@hotmail.com 
Sarcoidosis is an idiopathic, multi-systemic, granulomatous disease which is often seen in young adults. It is usually characterized by hilar lymphadenopathy, pulmonary infiltration, skin, and eye lesions and also noncaseating granulomatous inflammation in the affected organs $(1,2)$. It most commonly involves the lungs. Although each part of the body can be affected, lung (90\%), peripheral lymphatic (50 to $75 \%$ ), skin (60 to $80 \%$ ), liver (60 to $80 \%)$, bone ( 1 to $35 \%)$, heart and joints $(30 \%)$, eye $(17 \%)$, spleen $(15 \%)$, and salivary glands $(5 \%)$ can be affected (3). Cough and dyspnea are the most common symptoms, and the majority of the patients are asymptomatic. Abdominal involvement is detected in 5 to $15 \%$ of the patients with imaging modalities $(4,5)$. The most common findings on abdominal computed tomography (CT) are hepato-splenomegaly and lymphadenopathy. It rarely presents as multiple hypodense nodular lesions involving the liver and spleen (5). Herein, we present an asymptomatic and uncommon sarcoidosis case with an isolated nodular splenic involvement without liver involvement.

\section{CASE}

A 31 -year-old man was applied with cough, loss of appetite, dyspnea. On physical examination there was bilateral rhonchus's. His medical history was non-specific. Pulmonary function tests were normal. Bilateral hilar enlargement and interstitial micronodular infiltration predominantly in the upper and middle lung zones were present on chest radiography (Figure 1). On chest CT, there were conglomerated lymphadenopathies in all mediastinal compartments and bilateral hilar regions. Ground glass opacities which were accompanied by peribronchial wall thickening and increased densities accompanied by micronodules in right major fissure were observed (Figure 2A and B). Multiple hypodense nodular lesions in splenic parenchyma were detected on abdominal CT (Figure 3). Positron emission tomography computed tomography (PET-CT) was performed due to investigate the conglomerated mediastinal lymphadenopathies and other organ involvements. It revealed extensive lymphadenopathies with increased FDG uptake in all mediastinal compartments and diffuse ground glass opacities in both lungs. Small diffuse splenic nodular lesions with an increased FDG uptake were also reported. Increased blood ACE (78 U/L) levels were seen. Blood calcium level (9.6 $\mathrm{mg} / \mathrm{dL}$ ) and 24 -hour urine calcium level $(208 \mathrm{mg} / 24 \mathrm{~h}$ ) were within normal limits. Purified Protein Derived (PPD) test $(0 \mathrm{~mm})$ was negative. Eye examination findings were normal. The patient underwent bronchoscopic transbronchial biopsy which showed a benign histology. Subsequently, mediastinoscopy findings were reported as noncaseating granulomatous lymphadenitis. Due to the Stage 2 sarcoidosis and extrapulmonary organ involvement, steroid treatment was initiated. At six months, repeated CT showed regression of the lung and spleen lesions (Figure 4).

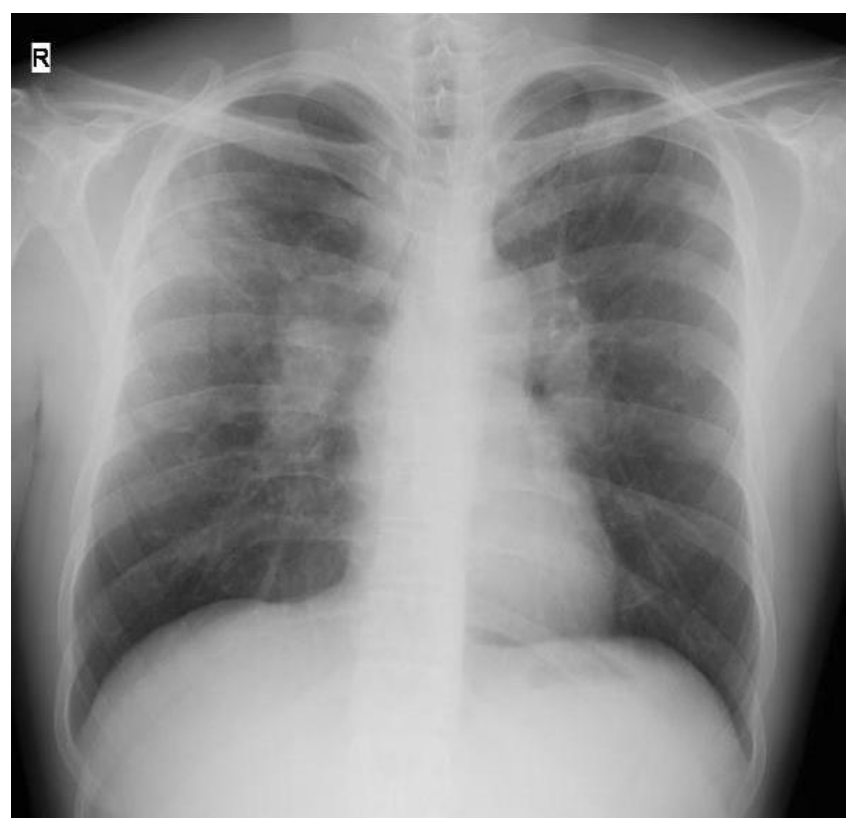

Figure 1: A Chest X-ray image showing bilateral hilar enlargement and parenchymal micronodular densities

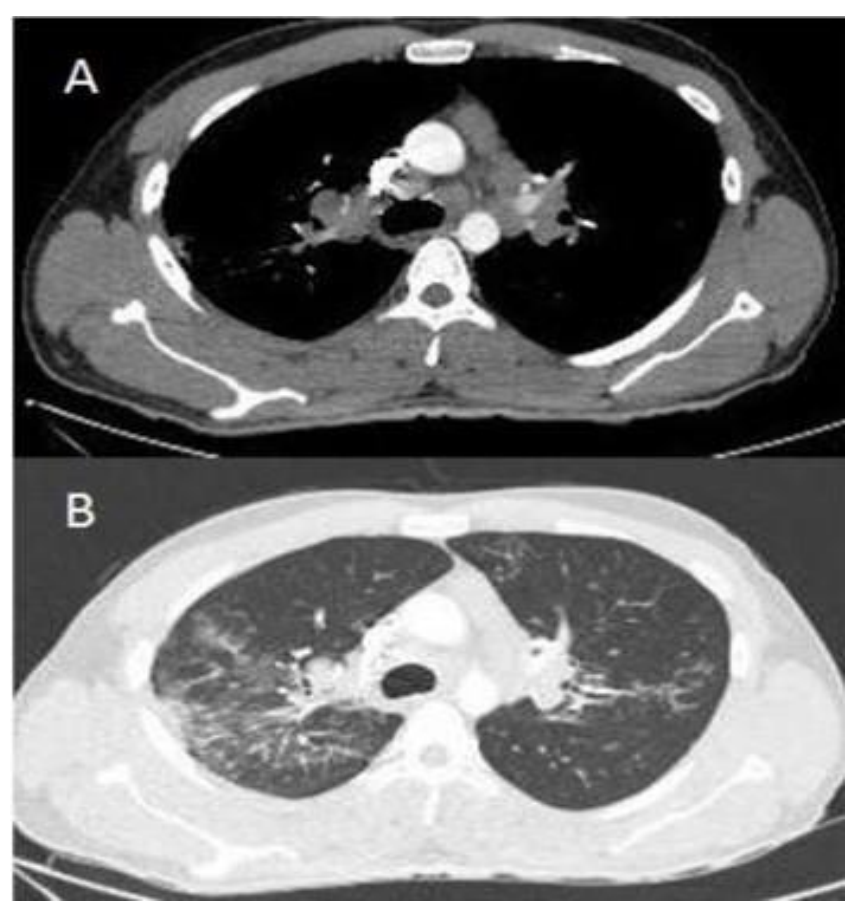

Figure 2A and B: A CT scan of the chest showing multiple mediastinal and hilar LAPs (A). Peribronchial wall thickening, ground glass opacities and micronodules in the lungs (B) 


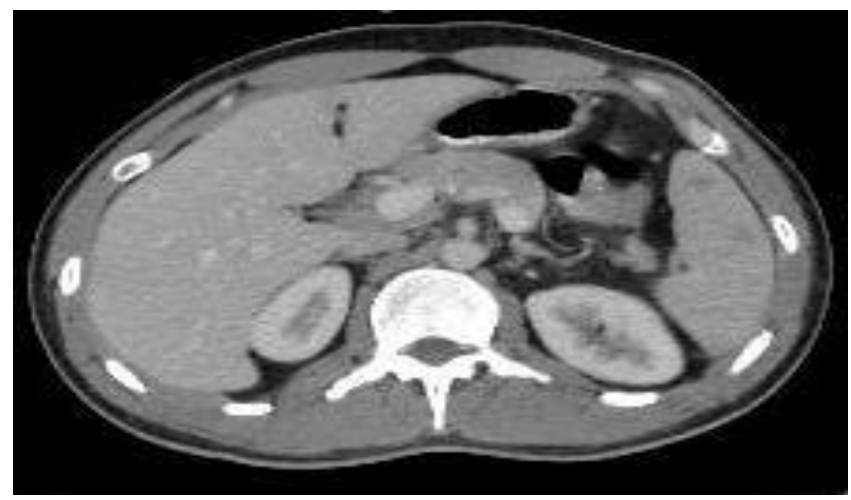

Figure 3: An abdominal CT scan showing multiple hypodense nodules in the spleen

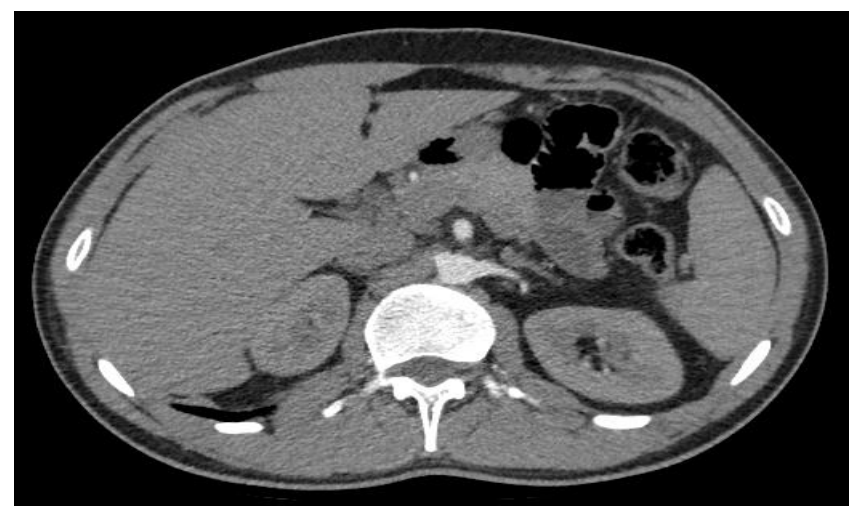

Figure 4: At six months of treatment, abdominal CT scan showing regression of the nodules in the spleen

\section{DISCUSSION}

Sarcoidosis is a granulomatous disorder of unknown etiology which most commonly involves the lung and lymph nodes. Although it may affect several systems, the clinical course and prognosis of sarcoidosis vary. Clinical appearance and symptoms depend on the duration of the disease, affected organs, extent of involvement, and activation of granulomatous event (6). While spontaneous remission of the disease occurs in one-third of the patients, 10 to $30 \%$ of patients have chronic disease $(4,7)$. Abdominal CT findings of sarcoidosis are LAP, splenomegaly, hepatomegaly, hypovascular nodular lesions in spleen and liver (8). Autopsy studies have shown that splenic involvement in sarcoidosis is the most common second involvement followed by lung with a ratio of 40 to $80 \%(9,10)$. Splenomegaly in physical examination is detected in 10 to $20 \%$ of the patients and it is often accompanied by hepatomegaly and rarely by hypercalcemia. In a biopsy-proven study of 49 patients, LAP in 20 of the cases, splenomegaly in 16 of them, hepatomegaly in two and hypodens nodular lesions in spleen and liver in seven of the patients were reported (11). In a review consisted of 20 patients who had splenic and hepatic hypodense lesions, isolated splenic spread is in seven patients, isolated hepatic spread is in 4 and both hepatic and splenic spread simultaneously was seen in nine patients (12). Multiple hepatic and splenic involvement of sarcoidosis in 39 cases and isolated splenic involvement were reported in only three cases in English literature (5). In an extended study with 6,074 sarcoidosis patients, there were massive splenomegaly in only $20(0.3 \%)$ of the 628 (10.3\%) patients with splenomegaly (13). In our case, there was no splenomegaly, but nodular splenic involvement. The patient was asymptomatic for abdominal clinical findings. Sarcoidosis can be rarely diagnosed, when extrapulmonary organ involvement is asymptomatic. In autopsy series, it has been demonstrated that lung involvement is followed by splenic involvement. Clinical course and prognosis of sarcoidosis vary. In one third of patients with spontaneous remission, the disease becomes chronic (10 to $30 \%$ ). The most commonly affected organs are the lungs, which increases morbidity and mortality (14).

\section{CONCLUSION}

Our case was an unusual Stage 2 sarcoidosis case with an isolated splenic involvement. Although extremely rare, it must be kept in mind by the radiologist and clinician in the differentials diagnosis of splenic nodules. Also, CT is a good option to visualize extrapulmonary organ involvement such as liver and spleen in the patients with suspected sarcoidosis.

\section{CONFLICTS OF INTEREST}

None declared.

\section{AUTHOR CONTRIBUTIONS}

Concept - Mu.Ç., M.Y., S.G.Ç., T.T.B., H.E.; Planning and Design - Mu.Ç., M.Y., S.G.Ç., T.T.B., H.E.; Supervision - Mu.Ç., M.Y., S.G.Ç., T.T.B., H.E.; Funding - M.Ç., S.G.Ç.; Materials - M.Ç., S.G.Ç.; Data Collection and/or Processing - M.Ç., S.G.Ç.; Analysis and/or Interpretation - M.Ç., S.G.Ç.; Literature Review - M.Ç., S.G.Ç.; Writing - M.Ç., S.G.Ç.; Critical Review - M.Ç., S.G.Ç.

\section{YAZAR KATKILARI}

Fikir - M.Ç., M.Y., S.G.Ç., T.T.B., H.E.; Tasarım ve Dizayn - M.Ç., M.Y., S.G.Ç., T.T.B., H.E.; Denetleme M.Ç., M.Y., S.G.Ç., T.T.B., H.E.; Kaynaklar - M.Ç., S.G.Ç.; Malzemeler - M.Ç., S.G.Ç.; Veri Toplama ve/veya İşleme - M.Ç., S.G.Ç.; Analiz ve/veya Yorum - 
M.Ç., S.G.Ç.; Literatür Taraması - M.Ç., S.G.Ç.; Yazıyı Yazan - M.Ç., S.G.Ç.; Eleştirel İnceleme - M.Ç., S.G.Ç.

\section{REFERENCES}

1. Baughman RP, Lower EE, du Bois RM. Sarcoidosis. Lancet 2003; 361:1111-8. [CrossRef]

2. Gezer NS, Başara I, Altay C, Harman M, Rocher L, Karabulut $N$, et al. Abdominal sarcoidosis: cross-sectional imaging findings. Diagn Interv Radiol 2015; 21:111-7. [CrossRef]

3. Thomas PD, Hunninghake GW. Current concepts of the pathogenesis of sarcoidosis. Am Rev Resp Dis 1987; 135:747-60.

4. Warshaver D. M. Splenic sarcoidosis. Semin Ultrasound CT MRI 2007; 28:21-7. [CrossRef]

5. Thanos L, Zormpala A, Brountzos E, Nikita A, Kelekis D. Nodular hepatic and splenic sarcoidosis in a patient with normal chest radiograph. Eur J Radiol 2002; 41:10-1. [CrossRef]

6. Hunninghake GW, Costabel U, Ando M, Baughman R, Cordier JF, du Bois R, et al. ATS/ERS/WASOG statement on sarcoidosis. American Thoracic Society/European Respiratory Society/World Association of Sarcoidosis and other Granulomatous Disorders. Sarcoidosis Vasc Diffuse Lung Dis 1999; 16:149-73.
7. Chen MY, Cai JT, Du Q, Wang LJ. Sarcoidosis of spleen presenting with solitary thrombopenia. Eur J Intern Med 2009; 20:e12. [CrossRef]

8. Yonenaga $Y$, Kushihata $F$, Inove $H$, Watanabe J, Tohyama $T$, Sugita $A$, et al. Sarcoidosis manifesting as hepatic and splenic nodules mimicking ovarian cancer metastases: A case report. Oncol Lett 2015; 10:2166-70. [CrossRef]

9. Mohan A, Sood R, Shariff N, Gulati MS, Gupta SD, Dutta AK. Sarcoidosis manifesting as massive splenomegaly: a rare occurrence. Am J Med Sci 2004; 328:170-2. [CrossRef]

10. Kataria YP, Whitcomb ME. Splenomegaly in sarcoidosis. Arch Intern Med 1980; 140:35-7. [CrossRef]

11. Folz SJ, Johnson CD, Swensen SJ. Abdominal manifestations of sarcoidosis in CT studies. J comput AssistTomogr 1995; 19:573-9. [CrossRef]

12. Scott GC, Berman JM, Higgins JL Jr. CT patterns of nodular hepatic and splenic sarcoidosis: a review of the literature. J Comput Assist Tomogr 1997; 21:369-72. [CrossRef]

13. Sharma SK, Mohan A. Sarcoidosis: global scenario \& Indian perspective. Indian J Med Res 2002; 116:221-47.

14. Baran A, Özşeker F, Güneylioğlu D, Bilgin S, Arslan S, Uyanusta Ç ve ark. Sarkoidoz: Yedi yıllık deneyim. Toraks Derg $2004 ; 5: 160-5$. 